\title{
Inter-colony comparison of diving behavior of an Arctic top predator: implications for warming in the Greenland Sea
}

\author{
Nina J. Karnovsky ${ }^{1, *}$, Zachary W. Brown ${ }^{1,2}$, Jorg Welcker ${ }^{3}$, Ann M. A. Harding ${ }^{4}$, \\ Wojciech Walkusz ${ }^{5,6}$, Andre Cavalcanti ${ }^{1}$, Johanna Hardin ${ }^{7}$, Alexander Kitaysky ${ }^{8}$, \\ Geir Gabrielsen $^{3}$, David Grémillet ${ }^{9,10}$
}

${ }^{1}$ Pomona College, Department of Biology, Claremont, California 91711, USA

${ }^{2}$ Stanford University, Department of Environmental Earth System Science, Stanford, California 94305, USA

${ }^{3}$ Norwegian Polar Institute, Polarmiljøsenteret, Tromsø, Norway

${ }^{4}$ Alaska Pacific University, Environmental Science Department, Anchorage, Alaska 99508, USA

${ }^{5}$ Institute of Oceanology PAS, Marine Ecology Department, 81-712 Sopot, Poland

${ }^{6}$ Department of Fisheries and Oceans, Winnipeg, Manitoba, R3T 2N6, Canada

${ }^{7}$ Pomona College, Department of Mathematics, Claremont, California 91711, USA

${ }^{8}$ Institute of Arctic Biology, Department of Biology and Wildlife, University of Alaska Fairbanks, Fairbanks, Alaska 99775, USA

${ }^{9}$ Centre National de la Recherche Scientifique, CEFE, F-34293 Montpellier, Cedex 5, France

${ }^{10}$ Percy FitzPatrick Insitute, DST/NRF Centre of Excellence, University of Cape Town, Rondebosch 7701, South Africa

\begin{abstract}
The goal of this study was to assess how diverse oceanographic conditions and prey communities affect the foraging behavior of little auks Alle alle. The Greenland Sea is characterized by 3 distinct water masses: (1) the East Greenland Current (EGC), which carries Arctic waters southward; (2) the Sørkapp Current (SC), which originates in the Arctic Ocean but flows north along the west coast of Spitsbergen; and (3) the West Spitsbergen Current (WSC), which carries warm Atlantic-derived water north. Each of these 3 water masses is characterized by a distinct mesozooplankton community. Little auks breeding adjacent to the EGC have access to large, lipid-rich Calanus copepods, whereas those adjacent to the SC have medium sized prey, while those near the WSC are limited to even smaller, less profitable prey. We used time-depth recorders to compare the time allocation and diving behavior of little auks adjacent to each of these 3 water masses. We predicted that birds in the EGC would not have to forage as intensively as those in the SC or WSC. We found that little auks foraging in the EGC spent less time at sea, spent less time flying, dived less often, made fewer long, deep dives, and made fewer V-shaped searching dives. This indicates that the EGC provides a more favorable foraging environment than do the warmer water masses to the east. Comparing the foraging behavior of little auk populations confined to Arctic versus Atlantic-influenced waters can provide insight into the potential impacts of future warming in the Greenland Sea.
\end{abstract}

KEY WORDS: Little auk - Alle alle - Calanus - Climate change · East Greenland Current · Sørkapp Current · West Spitsbergen Current · Time-depth recorder · Dovekie

Resale or republication not permitted without written consent of the publisher

\section{INTRODUCTION}

Climate change has significantly affected environmental conditions on a global scale, and warming has been especially pronounced in the Arctic. Largescale changes in the physical properties (e.g. sea ice, precipitation, air and sea temperatures) and the biological properties (e.g. phenology, species distribu- 
tions, community structure) in the Arctic present profound challenges for upper trophic predators (e.g. Moline et al. 2008). In order to assess the impacts of climate change on Arctic marine predators, it is important to understand how warming conditions influence their foraging behavior.

Little auks are among the most abundant top predators of the Arctic marine environment $\left(\sim 80 \times 10^{6}\right.$ ind.; Stempniewicz 2001), accounting for the ultimate consumption of $24 \%$ of total marine primary production at particular times and in some regions of the Arctic (Karnovsky \& Hunt 2002). They are important consumers of zooplankton, primarily copepods of the genus Calanus (e.g. Bradstreet \& Brown 1985, Karnovsky et al. 2003, 2010). Little auks are sub-surface foragers that make wing-propelled dives at sea. Due to their small size and high wing loading, flight is energetically costly (Livezey 1988). Both sexes participate in chick rearing, each day delivering multiple food loads that may each contain over 1000 prey items (Karnovsky et al. 2003). Little auks migrate to the Greenland Sea and other areas of the Atlantic Arctic to raise chicks during the short Arctic summer.

The Greenland Sea is characterized by 3 distinct water masses which differ in their origins and physical properties, and in the zooplankton community that they support (Fig. 1; Bourke et al. 1987; Wȩsławski et al. 1999). On the sea's western side, the East Greenland Current (EGC) carries polar water south from the Arctic Ocean (Bourke et al. 1987). The EGC is characterized by cold, low-salinity Arctic water and high densities of the large copepod Calanus hyperboreus (Hirche 1991). On the Greenland Sea's eastern side, the Sørkapp Current (SC), with Arctic origins, and the West Spitsbergen Current (WSC) from the Atlantic Ocean to the south, both flow north along the west coast of Spitsbergen (Fig. 1). The SC originates on the northeastern side of Spitsbergen and flows inshore of the WSC. The dominant copepod in the SC is the medium-sized Calanus glacialis (Karnovsky et al. 2003, 2010, Wȩsławski et al. 2006, Blachowiak-Samolyk et al. 2008, Kwaśniewski et al. 2010). The northeastern side of the Greenland Sea is influenced mainly by the relatively warm, high-salinity water of the WSC from the Atlantic (Aagaard et al. 1987). This water mass brings boreal zooplankton species such as the small Calanus finmarchicus into the High Arctic (Scott et al. 2000, Hop et al. 2002, Wȩsławski et al 2006, Blachowiak-Samolyk et al. 2008, Kwaśniewski et al. 2010). The Calanus copepods of these 3 water masses differ in size and energy content. For instance, a single copepodite stage 5 (C5) C. hyperboreus has 3

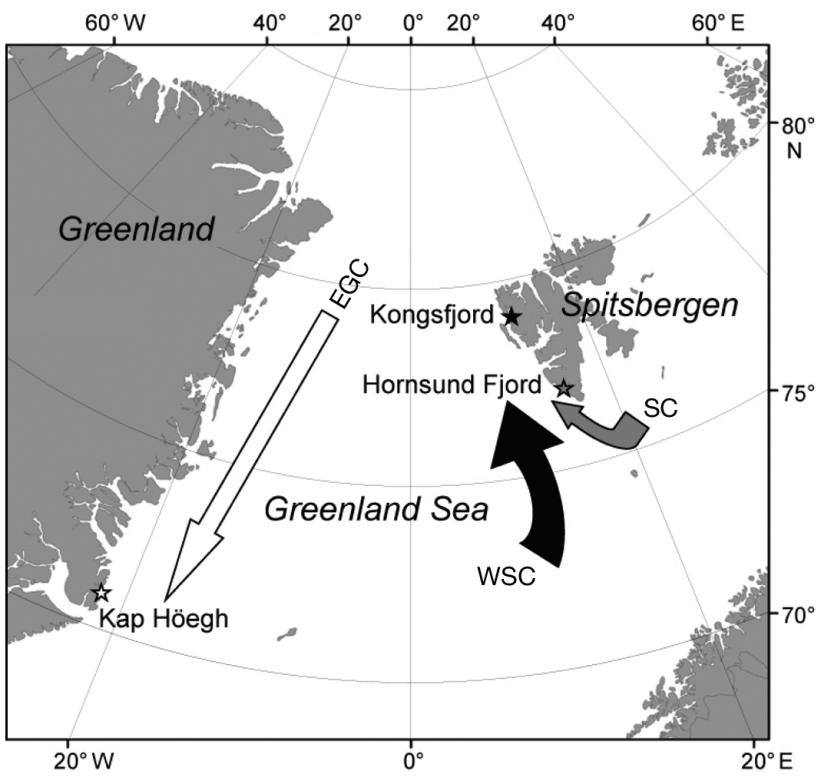

Fig. 1. Sites of little auk time-depth recorder deployment (is: colonies), July 2007. EGC: Arctic-derived East Greenland Current, SC: Arctic-derived Sørkapp Current, WSC: Atlantic-derived West Spitsbergen Current. Grey shade of stars $=$ affiliation of colony with current

times the energy content of a C5 C. glacialis and 25 times that of a C5 C. finmarchicus (Scott et al. 2000). Karnovsky et al. (2010) found that little auks feeding in the EGC fed chicks mainly C. hyperboreus, whereas those feeding in the SC fed chicks mainly C. glacialis.

We used time-depth recorders (TDRs) to compare, simultaneously, the diving behavior and time allocation of little auks breeding at 3 colonies that border the Greenland Sea: Kap Höegh, east Greenland ( $70^{\circ} 43^{\prime} \mathrm{N}, 21^{\circ} 38^{\prime} \mathrm{W}$; hereafter 'Greenland') adjacent to the EGC, Hornsund Fjord, southwest Spitsbergen ( $77^{\circ} 00^{\prime} \mathrm{N}, 15^{\circ} 22^{\prime} \mathrm{E}_{\text {; }}$ hereafter 'Hornsund') adjacent to the SC, and Kongsfjord, northwest Spitsbergen $\left(79^{\circ} 01^{\prime} \mathrm{N}, 12^{\circ} 25^{\prime} \mathrm{E}\right.$; hereafter 'Kongsfjord') adjacent to the WSC (Fig. 1). As central place foragers with high costs of flight, we predicted that little auks would be sensitive to prey conditions adjacent to their breeding colony. We predicted that Greenland birds foraging in the EGC, where the largest prey (Calanus hyperboreus) exists in high densities, would exhibit the least foraging effort. Specifically, we hypothesized that these birds spend less time at sea, dive less, undertake shorter bouts of diving, and make fewer searching dives. In contrast, we hypothesized that birds breeding at Kongsfjord adjacent to the warmer WSC with the smallest prey (C. finmarchicus) spend more time at sea, dive more often, undertake longer bouts of diving, and, overall, work harder to find food 
than either the Greenland or Hornsund birds. We hypothesized that Hornsund birds, being next to the SC with the medium size prey (C. glacialis), would exhibit foraging habits somewhere between the predictions for the other 2 colonies.

To test our hypotheses, we compared how little auks at the 3 colonies allocated their time to colony attendance, diving, flying, and resting at sea. In addition, we compared the number of dives made in each $24 \mathrm{~h}$, the number of dives per bout of diving, the duration of the dive, the depth of the dive, the shape of the dive (U-shaped versus $\mathrm{V}$-shaped), the rate of vertical ascent and descent, the dive efficiency, and the post-dive interval (PDI, surface recovery time between dives; Croll et al. 1992) among the 3 colonies. In a concurrent study utilizing the same instrumented birds, Welcker et al. (2009) described intercolony differences in the bimodal foraging strategy of little auks; their results indicate that little auks vary their foraging trip lengths in response to environmental conditions. Here, we focus on inter-colony differences in time allocation and diving behavior in these contrasting oceanographic conditions in order to gain insight into potential responses of the little auk to Arctic warming.

\section{MATERIALS AND METHODS}

To test our hypotheses, we attached TDRs to little auks breeding in each of the 3 colonies when chicks were between 1 and $18 \mathrm{~d}$ old. TDRs (Cefas G5 Data Storage Tags, $8 \mathrm{MB}$ of memory) were cylindrical in shape with a rounded tip to minimize water resistance (Wilson \& Culik 1994; Cefas Technology). The TDRs weighed $2.7 \mathrm{~g}$ in air, or $1.6 \%$ of the average initial mass of experimental birds. The TDRs had a cross-sectional area of $0.58 \mathrm{~cm}^{2}$, or $\sim 2 \%$ of the crosssectional area of adult little auks. They were programmed to record temperature and pressure every $5 \mathrm{~s}$ for up to $5 \mathrm{~d}$. When the birds dived below $1.5 \mathrm{~m}$, temperature and pressure readings were made every $0.2 \mathrm{~s}$ for the duration of the dive. TDRs were attached ventrally, allowing us to observe the time birds spent in flight versus sitting on the water (Tremblay et al. 2003). The impacts of TDR attachment and retrieval procedures were assessed in a number of ways (see Appendix 1). Differences between instrumented and non-instrumented birds were non-significant or marginally significant, so we are confident that the effect of the logger was negligible.

In order to determine what little auks were catching at sea to feed their chicks, we collected chick meals from the gular pouches of recaptured birds by gently scooping the prey with a small spoon. Diet samples were also collected from non-instrumented adults during early and mid-chick rearing when chicks were between 1 and $18 \mathrm{~d}$ old, at the same time that the TDRs were deployed (Greenland $\mathrm{n}=39$; Hornsund $n=55$; Kongsfjord $n=56$ ). We preserved chick meals in $<5 \%$ buffered formalin in seawater. We counted and identified all items of diet to the lowest possible taxon. We included partial diet samples in determining the composition of the prey species for each colony, but used only complete diet samples for estimating the average number of prey items taken per chick meal (Greenland $\mathrm{n}=30$; Hornsund $\mathrm{n}=46$; Kongsfjord $\mathrm{n}=54$ ). Data on the diets from Hornsund are also presented in Kwaśniewski et al. (2010). Following the procedures used in Karnovsky et al. (2003) and Kwaśniewski et al. (2010) we used published formulas for dry weight (DW) of different zooplankton species and estimated energy content using $26 \mathrm{~kJ}$ per g DW (Wȩsławski et. al. 1994) to calculate the energy content of the prey delivered to chicks. We combined data on the diets from birds sampled during early and mid-chick rearing in our analyses because, as in Karnovsky et al. (2003), we did not find seasonal differences in the number or composition of the diet items. To determine fledging success (number of chicks fledged:number hatched), we marked active nest sites during late incubation and visited every 2 to $5 \mathrm{~d}$ until fledging. We considered chicks that disappeared from the nest after $20 \mathrm{~d}$ to be fledged (Harding et al. 2004).

We defined a dive as any discrete underwater period in which the bird reached a depth of at least $1.5 \mathrm{~m}$ (to eliminate artifacts triggered by wave action or other activity). We eliminated the first portion of the dive records (just after the birds were released) if it was obvious that the bird was preening the device or otherwise behaving abnormally (sensu Croll et al. 1992). We considered the birds to have completed a foraging trip when the temperature rose to colony temperatures and the pressure stabilized in the $5 \mathrm{~s}$ data logs. Within a foraging trip, we considered a bout of diving to be a series of 1 or more dives with short intervals $(<2 \mathrm{~min})$ separating each dive (Monaghan et al. 1994). Thus, if the time which had elapsed between 2 successive dives were $<2 \mathrm{~min}$, we defined it as the PDI (recovery time) corresponding to the previous dive; if it were $>2 \mathrm{~min}$, we defined it as the end of a bout of diving. On the basis of temperature and pressure in the $5 \mathrm{~s}$ data log, we classified the time that birds allocated to 7 different behaviors: (1) flying to sea, (2) diving (including the entire dive 
cycle of descent, bottom time, ascent, and PDI), (3) sitting on water (not including PDI), (4) flying while at sea, (5) sitting on ice, (6) flying back to the colony, and (7) time at the colony (we were unable to differentiate between colony time inside or outside the nest). We defined sitting on ice when the logger recorded icy temperatures with a constant surface pressure reading. Temperatures occasionally spiked when the birds placed their legs against the logger, causing these increases. The time when they hopped back in the water was easy to determine based on temperature readings.

We calculated the number of dives each bird made in $24 \mathrm{~h}$ by counting all of the dives made and dividing this by the number of days that the TDR had been deployed. Similarly, by summing the durations of all dives and dividing by the total time of logger deployment, we determined the percentage of time each bird spent underwater.

For all fine-scale analyses of dive parameters (including average sea temperature, maximum depth, duration of dive, PDI, bottom time, dive efficiency, and rates of vertical descent and ascent) we analyzed data collected every $0.2 \mathrm{~s}$ during diving. We defined bottom time as the portion of the dive in which the bird was at $\geq 80 \%$ of the maximum depth of the dive (Kuroki et al. 2003). We defined the metric 'bottom frequency' as the bottom time divided by the total duration of the dive, and used this as an objective proxy for the dive's profile. A dive with high bottom frequency is a more U-shaped dive; a dive with low bottom frequency is more V-shaped. As in Ydenberg \& Clark (1989) and Croll et al. (1992), we defined dive efficiency as bottom time divided by the total dive cycle (dive duration + PDI). We considered descent and ascent times to be the underwater periods before and after bottom time, respectively, from which we calculated vertical velocities.

We ran mixed-effects linear models (LMEs) with location as a fixed explanatory variable and individual as a random effects term to test for inter-colony differences in the means of various dive parameters. Response variables included average temperature, maximum depth, duration of dive, PDI, vertical descent rate, vertical ascent rate, bottom frequency, number of dives per bout, duration of the foraging trip, and the percentage of time allocated to colony attendance, flying, diving, and resting at sea. In addition, we used LMEs to assess the effect of dive duration on the PDI and whether this effect differed between study sites. Similarly, we used LMEs to test for inter-colony differences in the effect of maximum dive depth on the rates of vertical descent and ascent. In these models, 'individual' and the interaction between 'individual' and 'dive duration' and 'maximum depth', respectively, were included as random effects. We log-transformed data when appropriate to meet the condition of normality.

We used simple 1-way analysis of variance (1-way ANOVA) to test for inter-colony differences in the number of dives per $24 \mathrm{~h}$ and the time spent underwater. We used Pearson's chi-square tests to assess differences among the 3 colonies in the frequency distribution of the number of dives per bout of diving. In order to assess inter-colony differences in binary variables, we used logistic regression ( $\operatorname{LogR}$ ) to test the odds of a particular outcome as explained by location as a fixed effect and individual as a random effect. The binary variables that we used were dives per bout (predicting the odds that a bout of diving was short: 1 to 5 dives), and maximum depth (predicting the odds that a dive was deep: $\geq 25 \mathrm{~m}$ maximum depth).

We performed linear discriminant analysis (LDA) to determine how well individuals could be classified to colony on the basis of their dive characteristics. We included the following parameters in the model: percentage of time spent underwater, PDI, dive efficiency, maximum depth, duration of dive, average temperature of dives, number of dives per $24 \mathrm{~h}$, bottom time, bottom frequency, vertical ascent rate and vertical descent rate. Each bird's colony was predicted by a model built with the bird in question removed.

We used the statistical package R v. 2.6.2. (The R Development Core Team 2008) using the packages nlme, lme4, and MASS. We report all data as mean and associated standard error unless stated otherwise.

\section{RESULTS}

We recaptured a total of 24 birds from the 3 colonies: 6 at Greenland ( $43 \%$ of birds with TDRs), 11 at Hornsund $(63 \%)$ and 7 at Kongsfjord (54\%). Temperature and pressure were recorded every $5 \mathrm{~s}$ over a total of 77.2 bird-days: 12.5 in Greenland, 38.8 in Hornsund and 25.9 in Kongsfjord. Temperature and pressure were recorded every $0.2 \mathrm{~s}$ during 23895 dives (Greenland 3490; Hornsund 12781; Kongsfjord 7624). Through molecular sexing, we found that there were uneven numbers of instrumented males and females from each colony (male to female ratios: Greenland 1:5; Hornsund 4:7; Kongsfjord 6:1). We tested for differences in diving behav- 
iors between male and female birds from Hornsund where there were more equal numbers of each sex instrumented. We observed no differences in diving behavior (PDI length, ascent rate, descent rate, bottom frequency, maximum depth, number of dives per bout of diving, length of foraging trip or allocation of time to different behaviors) between sexes.

The maximum depth attained by any bird was $37.8 \mathrm{~m}$ (Hornsund), and the maximum duration of a dive was $79.2 \mathrm{~s}$ (both Hornsund and Kongsfjord). However, across all colonies, the maximum depth (mean $\pm \mathrm{SD}$ ) of dives was $9.9 \pm 6.9 \mathrm{~m}$,

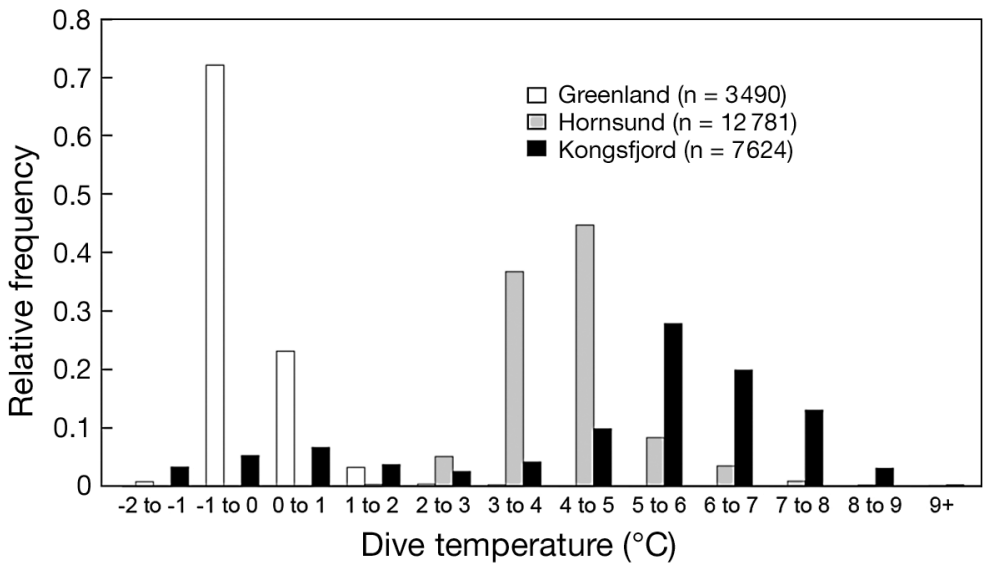

Fig. 2. Alle alle. Relative frequency distributions of the average temperatures of little auk dives for 3 colonies along the Greenland Sea and only $3.9 \%$ of dives reached $\geq 25 \mathrm{~m}$. Overall, the duration (mean \pm SD) of dives was $37.0 \pm 15.5 \mathrm{~s}$, and the duration was positively related to maximum dive depth $\left(\mathrm{r}_{24}=0.716 ; \mathrm{p}<\right.$ 0.0001 , averaged per bird). In all colonies, vertical velocities were generally higher in the descent phase than in the ascent phase, giving rise to a high frequency of variable 'skewed right' shaped dives (Schreer et al. 2001).

\section{Inter-colony comparison of foraging and diving behavior}

The colonies differed in the average temperature of the water in which the birds dived (Greenland: $-0.25 \pm 0.01^{\circ} \mathrm{C}_{i}$ Hornsund: $4.20 \pm 0.01^{\circ} \mathrm{C}_{i}$ Kongsfjord $4.79 \pm 0.03^{\circ} \mathrm{C}$; LME: $F_{2,21}=128.757 ; \mathrm{p}<0.0001$ ). Birds from Greenland had the highest frequency of lowtemperature dives, most being below $0^{\circ} \mathrm{C}$, while birds at Kongsfjord had the highest frequency of high-temperature dives $\left(5\right.$ to $\left.8^{\circ} \mathrm{C}\right)$, confirming the oceanographic differences in the waters adjacent to the colonies (Fig. 2).

\section{Chick diet and fledging success}

There were inter-colony differences in the prey fed to chicks. Greenland birds took a far greater percentage of the energy-rich Calanus hyperboreus than did the birds from Hornsund or Kongsfjord (Fig. 3). They also took a greater percentage of non-calanoid food items, mainly the amphipod Apherusa glacialis $(13.8 \%)$. Hornsund and Kongsfjord birds primarily took the smaller C. glacialis and, to a lesser extent, C. finmarchicus. There were significant differences in average abundance of diet items per complete
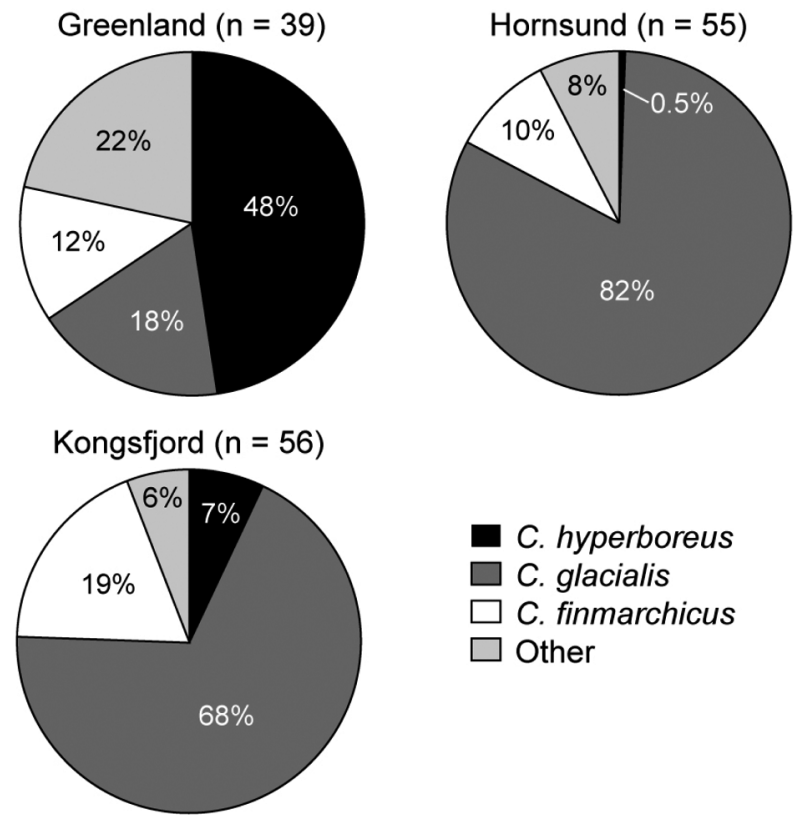

Fig. 3. Alle alle. Composition (by number; chiefly Calanus spp.) of chick meals brought back from the sea by chickrearing little auks at 3 colonies along the Greenland Sea. Partial diet samples were included in determining percentage composition, but not in determining the average number of prey items

chick meal (1-way ANOVA $F_{2,95}=25.038, \mathrm{p}<0.0001$; $607 \pm 80$ for Greenland, $1427 \pm 111$ for Hornsund, and $1465 \pm 122$ for Kongsfjord). There was a corresponding difference in the average energy content of these meals (1-way ANOVA $F_{2,95}=14.27, \mathrm{p}<0.0001 ; 15.2 \pm$ $1.2 \mathrm{~kJ}$ Greenland; $21.9 \pm 1.6 \mathrm{~kJ}$ Hornsund; $22.7 \pm$ $1.4 \mathrm{~kJ}$ Kongsfjord). This imbalance of energy was partially mitigated by an inter-colony difference in feeding rates, as summarized in Welcker et al. (2009). 
On average, Greenland birds delivered 4.9 meals d $^{-1}$, Hornsund birds 4.1 meals $\mathrm{d}^{-1}$, and Kongsfjord birds,

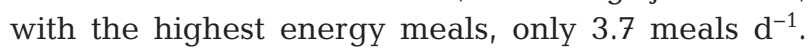
This leads to an estimated chick consumption rate of $\sim 148 \mathrm{~kJ} \mathrm{~d}^{-1}$ in Greenland, $177 \mathrm{~kJ} \mathrm{~d}^{-1}$ in Hornsund and $\sim 168 \mathrm{~kJ} \mathrm{~d}^{-1}$ in Kongsfjord. Fledging success was high at all colonies: Greenland 93.4\% ( $\mathrm{n}=61$ monitored nests); Hornsund $\geq 87.5 \%(\mathrm{n}=32)$; and Kongsfjord $97.6 \%(n=42)$.

Time allocation

Greenland birds spent a greater proportion of time at the colony $(42.5 \%)$ compared to Hornsund birds $(30.3 \%)$ or Kongsfjord birds $(22.5 \%)$, and less time at sea (LME: $F_{2,19}=6.511, \mathrm{p}=0.007 ;$ Fig. 4). During time at sea, Hornsund birds devoted more time to active diving (LME: $F_{2,21}=5.848, \mathrm{p}=0.009$; Fig. 4). At sea, Greenland birds spent the smallest proportion (though non-significant) of time flying (LME: $F_{2,21}=$
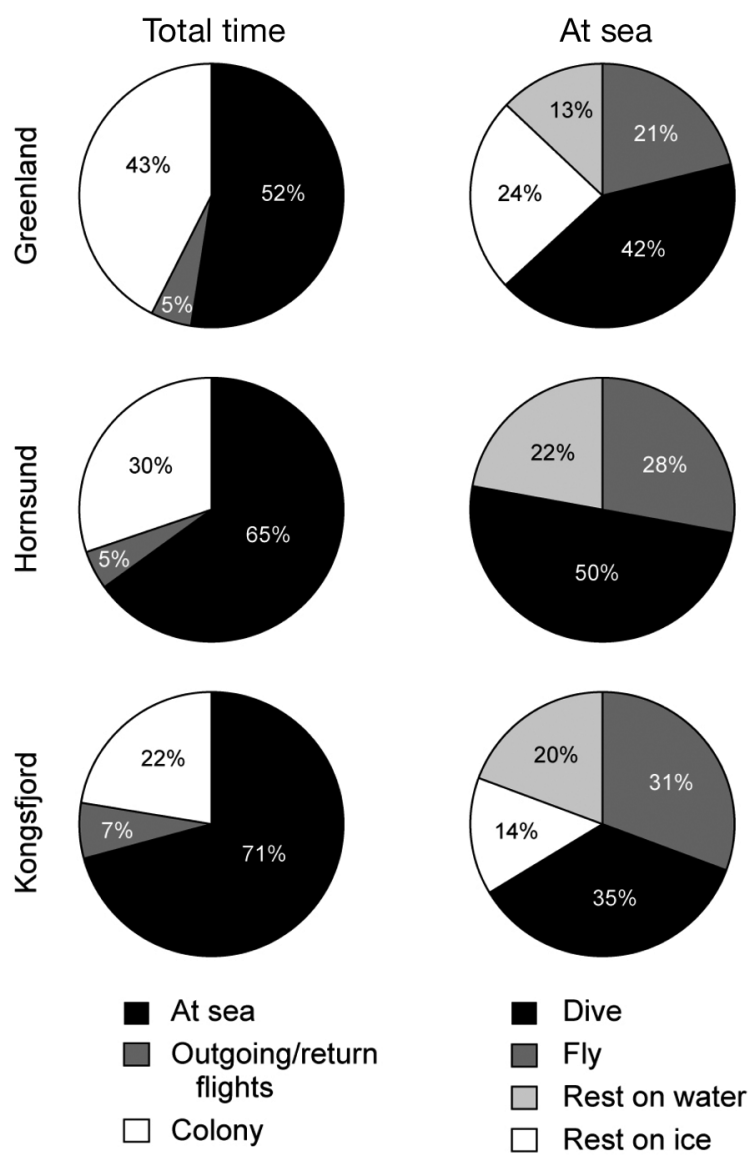

Fig. 4. Alle alle. Overall time partitioning and time partitioning at sea for little auks rearing chicks at 3 colonies along the Greenland Sea
3.248, $\mathrm{p}=0.059$ ) and the greatest proportion of time resting on ice or water (LME: $F_{2,21}=8.472, \mathrm{p}=0.002$; Fig. 4).

\section{Foraging trips}

The duration of foraging trips differed among the colonies, with Greenland birds making no trips over $13 \mathrm{~h}$, whereas all birds at both Hornsund and Kongsfjord made much longer trips (Fig. 5A; for a discussion of how trip length varied among colonies see Welcker et al. 2009).

The proportion of time spent flying during foraging trips differed only marginally among the 3 colonies (Fig. 4), because Kongsfjord birds made longer foraging trips. However, their average total flight time (transiting to and from foraging areas and flying around between bouts of diving) during trips (2.9 \pm $0.4 \mathrm{~h})$ was far greater than for the Hornsund $(1.7 \pm$ $0.3 \mathrm{~h})$ or the Greenland birds $(1.1 \pm 0.2 \mathrm{~h})$ (LME: $F_{2,21}=4.6, \mathrm{p}=0.022$ ).

\section{Dives}

The distribution of the number of dives per bout of diving was different among the colonies $\left(\chi^{2}=85.7\right.$; df $=18 ; \mathrm{p}<0.0001$; Figs. 5B \& 6). Greenland birds made a far lower proportion $(28.0 \%)$ of diving bouts with very few (1 to 5) dives compared with the birds at Hornsund (44.5\%; LogR: p $=0.034$ ) or Kongsfjord (44.9\%; LogR: $p=0.021$; Figs. 5B \& 6). Only the birds at Hornsund and Kongsfjord made extended bouts of diving with over 75 dives (Figs. 5B \& 6).

Greenland birds made fewer dives per $24 \mathrm{~h}$ than did the birds from other colonies, making $285 \pm$ 29 dives compared to those from Hornsund (473 \pm 49 ) and Kongsfjord $(340 \pm 25)$ (1-way ANOVA: $F_{2,21}=$ $5.337 ; \mathrm{p}=0.013)$. There was no inter-colony difference in the mean maximum depth of dives (Fig. 5C; LME: $\left.F_{2,21}=3.157 ; \mathrm{p}=0.0633\right)$. However, Greenland birds had a lower frequency of deep $(\geq 25 \mathrm{~m})$ dives $(1.7 \%)$ than either Hornsund $(4.0 \%$; LogR: $p=0.004)$ or Kongsfjord birds (4.8\%; LogR: $\mathrm{p}=0.003)$. Hornsund birds made the highest frequency of shallow $(<10 \mathrm{~m})$ dives $(68.7 \%)$. The colonies did not differ in the overall duration of dives (LME: $F_{2,21}=1.796 ; \mathrm{p}=$ 0.1905); however, in keeping with the strong, positive depth-duration relationship, birds from Hornsund and Kongsfjord made more long dives ( $\geq 50 \mathrm{~s}$ ) compared to the Greenland birds (13.8\% Greenland, $20.2 \%$ Hornsund, $22.9 \%$ Kongsfjord). 

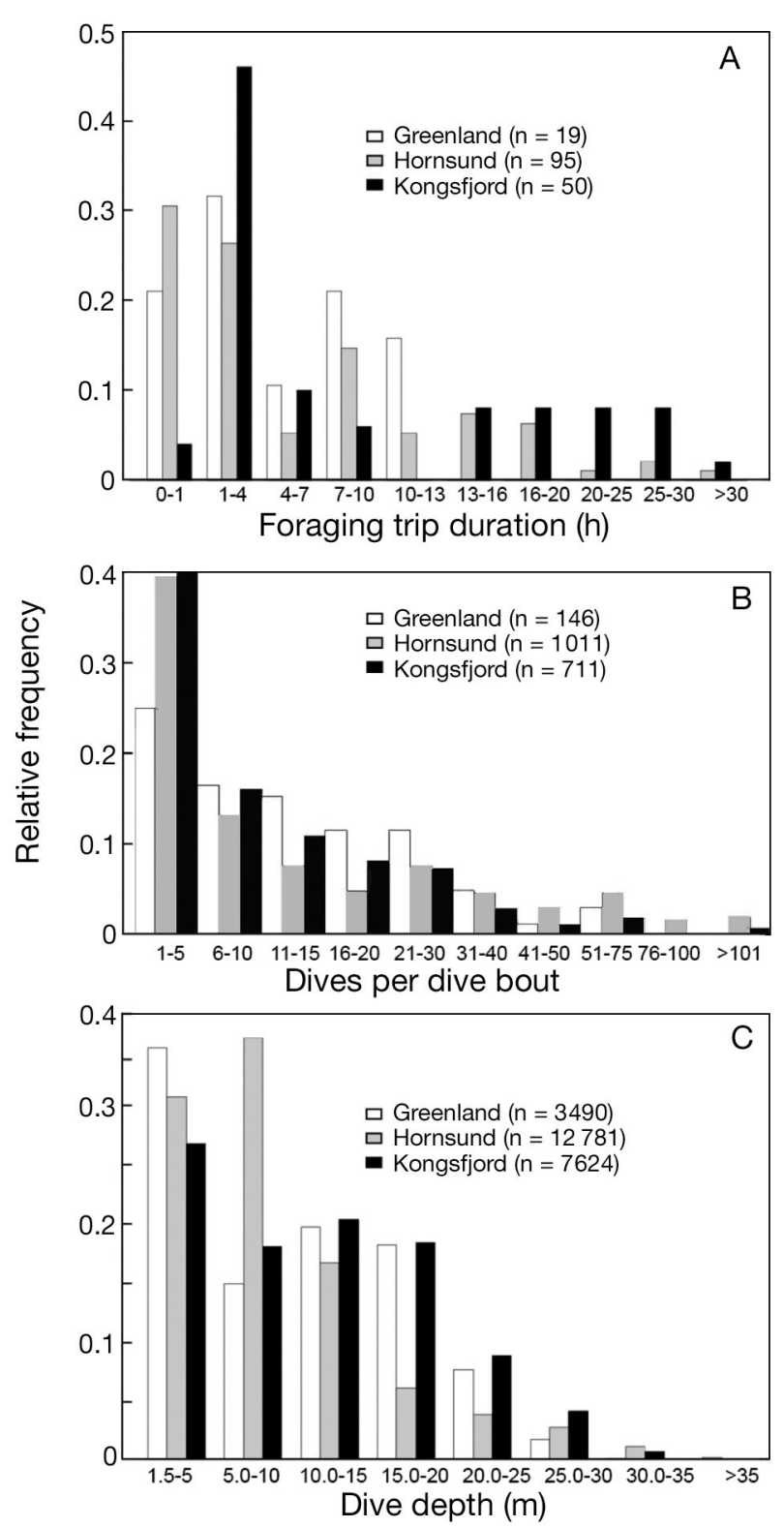

Fig. 5. Alle alle. Relative frequency distributions of diving attributes for little auks rearing chicks at 3 colonies along the Greenland Sea. (A) Length of foraging trip (h), (B) number of dives per bout of diving, and (C) maximum dive depth (m)

There was a tendency for Kongsfjord birds to make fewer U-shaped dives $(65.2 \%$ of Greenland dives had bottom frequency $\geq 0.5$; Hornsund $63.0 \%$; Kongsfjord $55.0 \%$ ). Kongsfjord birds had a higher frequency of more $\mathrm{V}$-shaped dives; however, this difference was non-significant (LME: $F_{2,21}=2.039 ; \mathrm{p}=$ 0.1551; Fig. 7A).

There were inter-colony differences in the vertical ascent rates of dives (LME: $F_{2,21}=27.825 ; \mathrm{p}<0.0001$;
Fig. $7 \mathrm{~B}$ ) but not in vertical descent rates (LME: $F_{2,21}=$ $0.247 ; \mathrm{p}=0.784 ;$ Fig. 7C). In the descent phase, all colonies had similar average vertical velocities (around $1.25 \mathrm{~m} \mathrm{~s}^{-1}$; Fig. 7C), but in the ascent phase, Hornsund birds generally moved more slowly vertically $\left(0.741 \pm 0.003 \mathrm{~m} \mathrm{~s}^{-1}\right)$ than either Greenland birds $\left(1.017 \pm 0.005 \mathrm{~m} \mathrm{~s}^{-1}\right)$ or Kongsfjord birds $\left(1.019 \pm 0.005 \mathrm{~m} \mathrm{~s}^{-1}\right.$; Fig. 7B). The interaction between depth and colony was also significant; therefore, differences in ascent rate differed across colonies for some depths but not for others (LME: $\left.F_{2,16438}=4.0872 ; \mathrm{p}=0.0168\right)$.

When modeling PDI with colony and dive duration, there was no significant inter-colony difference in mean PDI (LME $\left.E_{\text {Colony }}: F_{2,21}=1.408 ; \mathrm{p}=0.2668\right)$. However, PDI significantly increased with dive duration $\left(\mathrm{LME}_{\text {Dive duration }}: F_{1,22080}=173.462 ; \mathrm{p}<0.0001\right)$ at all

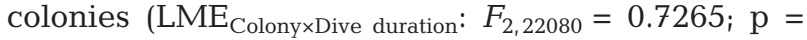
$0.4836)$. There was no significant inter-colony difference in dive efficiency (LME: $F_{2,21}=1.426 ; \mathrm{p}=$ $0.2627)$.

Using LDA, 21 of the 24 birds were correctly classified to their colony on the basis of their diving behavior alone. All 6 Greenland birds were correctly classified, 1 Hornsund bird was misclassified as a Kongsfjord bird, and 2 Kongsfjord birds were misclassified as Hornsund birds.

\section{DISCUSSION}

We found strong inter-colony differences in the foraging behavior of little auks. These differences were a response to contrasting oceanographic conditions and prey at the 3 colonies. As observed in 2005, birds at the Greenland colony foraged in the EGC $\left(<0^{\circ} \mathrm{C}_{i}\right.$ Fig. 2) on larger, lipid-rich prey, primarily Calanus hyperboreus and the ice-associated amphipod Apherusa glacialis (Fig. 3; Karnovsky et al. 2010). Furthermore, birds at Hornsund foraged in the SC for the intermediate sized copepod C. glacialis, in keeping with observations of previous years (Karnovsky et al. 2003, 2010). In this study, Kongsfjord birds took mainly C. glacialis, despite foraging primarily in the WSC $\left(>5^{\circ} \mathrm{C}\right)$, where the smaller $C$. finmarchicus is dominant (Karnovsky et al. 2010). A similar pattern was described by Kwaśniewski et al. (2010) in their comparison of chick diets and zooplankton collected in net tows at Hornsund and Magdalenefjorden, a colony north of Kongsfjord that is also heavily influenced by the WSC.

The inter-colony differences in foraging behavior were apparent both in how they allocated their time 


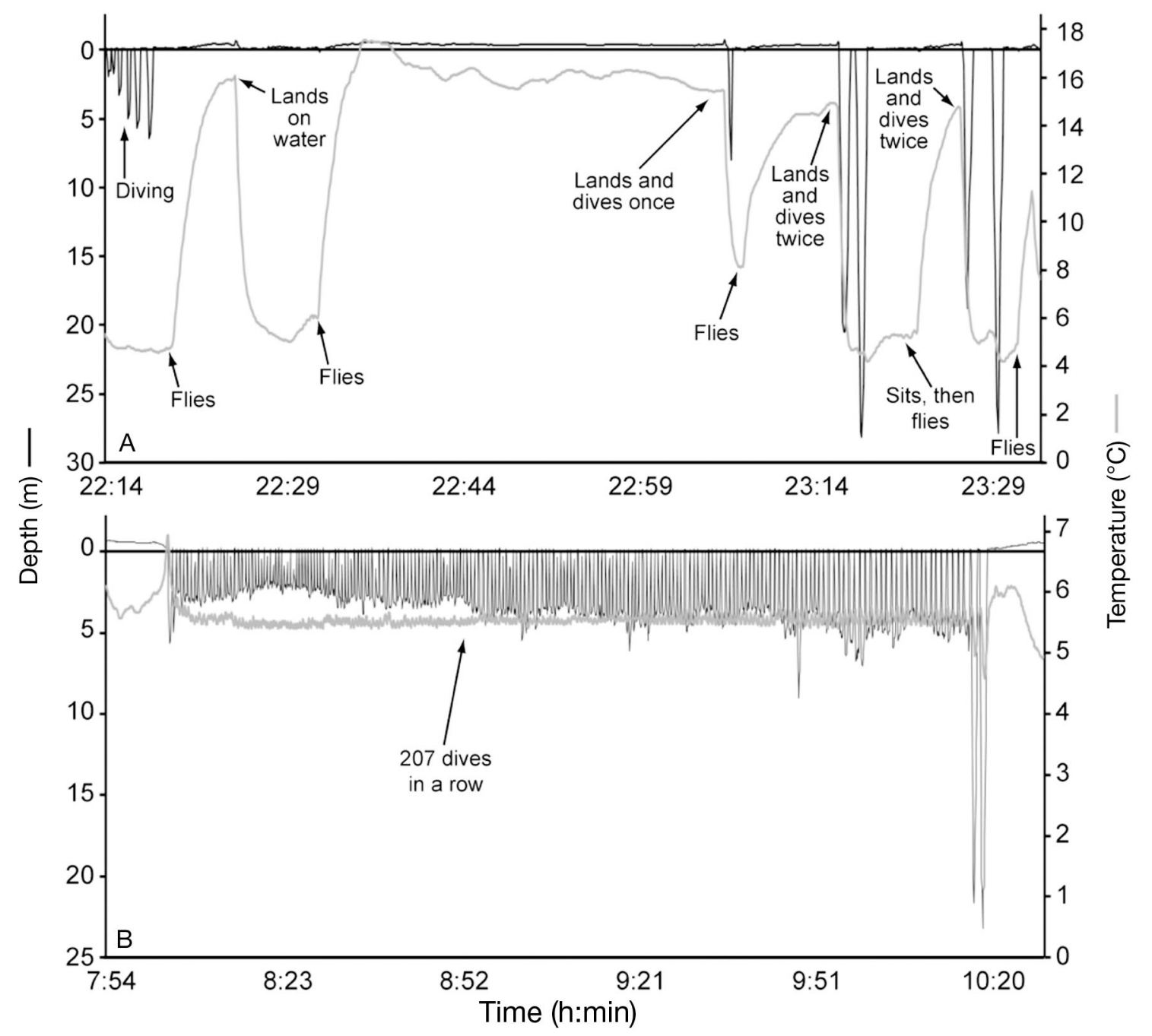

Fig. 6. Alle alle. Two dive profiles showing the high variability in the diving bouts of breeding little auks foraging in the Greenland Sea. (A) Short bouts interrupted by flights probably represent searching behavior (Hornsund bird 24). (B) This extended bout probably represents intensive foraging for prey at 3 to $6 \mathrm{~m}$ depth (Kongsfjord bird 767)

and in their diving behavior. As predicted, Greenland birds made shorter foraging trips compared to Kongsfjord or Hornsund birds, and accordingly devoted a greater proportion of time to colony attendance (Fig. 4). This may be a consequence of the higher quality of the prey in Greenland. In a similar fashion, Harding et al. (2007) found that time spent at the breeding colony increased in common murres foraging in prey-rich areas.

As we predicted, Greenland birds made fewer dives in $24 \mathrm{~h}$ periods and spent less time underwater compared to birds from the other colonies. However, in terms of numbers of dives per bout of diving, our predictions were not borne out. We predicted that Greenland birds would make shorter bouts of diving in response to high-quality prey, yet Kongsfjord and Hornsund birds made many more bouts with few
(1 to 5 ) dives. These birds would frequently make bouts of 1 to $5 \mathrm{~V}$-shaped dives before flying to a different spot (Fig. 6). V-shaped dives are generally interpreted as 'searching' dives (e.g. Wilson et al. 1996). If the bird does not encounter prey, it spends little time on the bottom phase of the dive, resulting in a V-shaped dive profile. We therefore propose that these bouts with few dives may represent unsuccessful searching for prey, and probably reflect a patchy spatial distribution of prey around Kongsfjord and Hornsund. The low frequency of searching dives made by Greenland birds, however, indicates that prey are more easily located there. In addition to a high frequency of 'searching', the Hornsund and Kongsfjord birds occasionally made extended bouts with over 75 dives (Figs. 5B \& 6). These long bouts may reflect lower densities of prey, or the fact that 

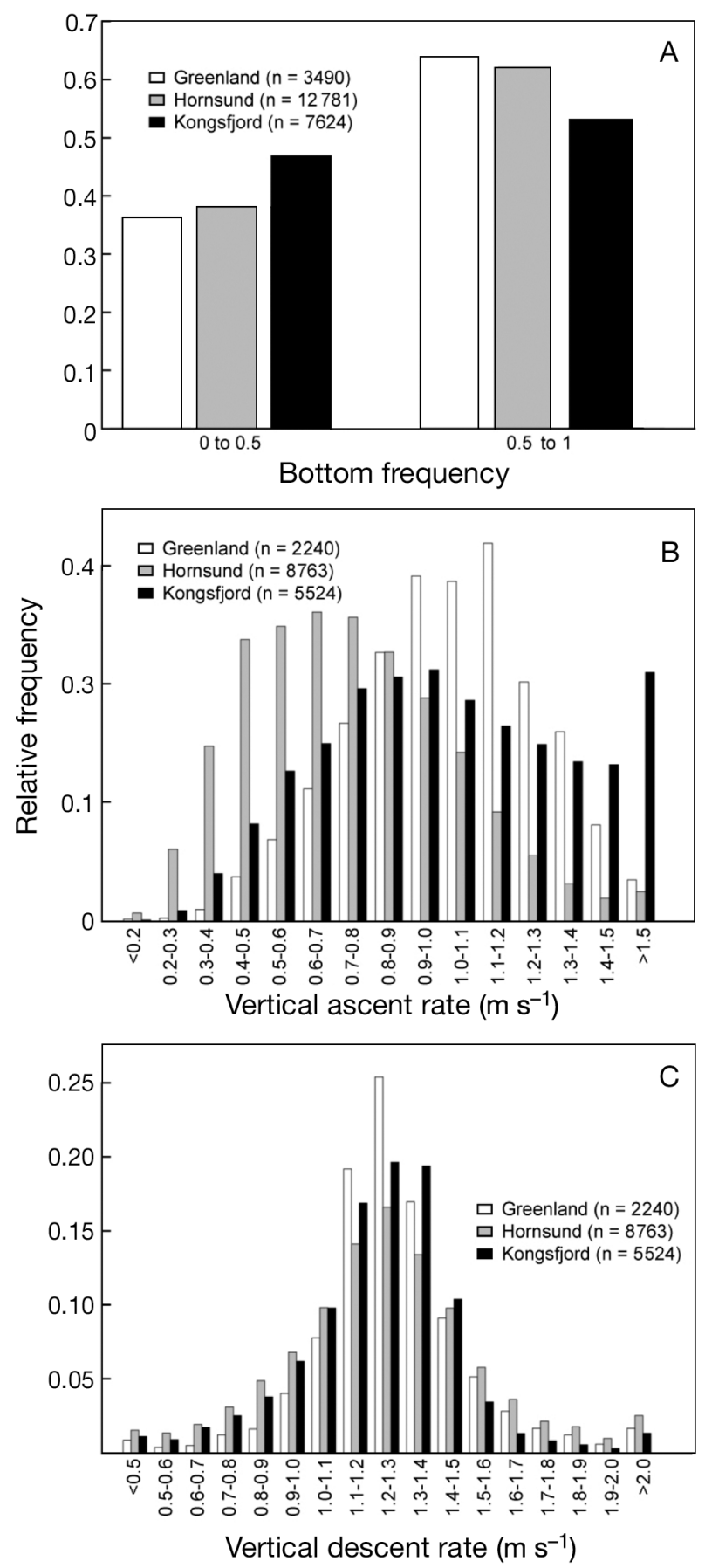

Fig. 7. Alle alle. Relative frequency distributions of diving attributes for little auks rearing chicks at 3 colonies along the Greenland Sea. (A) Bottom frequency, (B) vertical ascent rate, and $(\mathrm{C})$ vertical descent rate

prey were smaller, forcing these birds to collect far more prey items per food load. These conditions might also be responsible for the greater frequency of exceptionally deep, long dives on the eastern side of the Greenland Sea.
Little auks from different colonies all ascended at a slower rate than they descended. They may travel more slowly during the ascent in order to better utilize the 'silhouette effect', or the ability to more easily view prey items when back-lit against the water's surface (Wilson et al. 1996). This pattern was most pronounced at Hornsund, where vertical ascents were on average $50 \%$ slower than vertical descents. Hornsund birds also made the greatest proportion of dives to $<10 \mathrm{~m}$ maximum depth (Fig. 5C). Slower ascent rates and shallower dives at Hornsund are probably connected to the vertical distribution and density of Calanus glacialis there.

On the basis of their dive characteristics alone, 21 out of 24 birds were classified to their correct colony. All the Greenland birds could be correctly classified; however, there were 3 mis-classifications between Hornsund and Kongsfjord birds. This reflects the fact that the east-west differences in diving behavior among the 3 colonies were most striking. All the inter-colony differences we found point to the fact that the EGC provides a more favorable foraging environment than the WSC and SC on the eastern side of the Greenland Sea.

In another high-Arctic inter-colony comparison of alcid foraging and diving behavior, Falk et al. (2002) found differences in thick-billed murres Uria lomvia foraging on the east and west sides the North Water Polynya. They attributed the increased depths of diving, and the increased time spent diving at the eastern colony, to zonal variation in oceanographic conditions. Likewise, in this study, differences in little auk foraging and diving in the Greenland Sea were driven by east-west differences in the size and distribution of prey. The diving behavior generally exhibited by Hornsund and Kongsfjord birds was similar to that found in common murres Uria aalge foraging off the Shetland Islands during a poor food year (Monaghan et al. 1994). When food was scarce, birds made longer foraging trips, spent more time flying and diving, and made more dives per bout of diving than they did when prey were more abundant. However, by making this adjustment, birds maintained high breeding success during those poor food years (Monaghan et al. 1994, Uttley et al. 1994).

Despite strong inter-colony differences in foraging behavior and dive characteristics, fledging success was high at all colonies. This implies that oceanographic conditions across the Greenland Sea were adequate for the successful raising of chicks. On average, Greenland birds delivered less than half the number of prey items than did birds foraging on the eastern side of the Greenland Sea, but they were 
able to feed their chicks more frequently. In contrast, birds at Hornsund and Kongsfjord, feeding on smaller prey, adjusted their foraging behavior to bring back higher numbers of prey. Even though Hornsund and Kongsfjord birds fed their chicks less frequently, they seem to have adequately compensated for this by delivering more energy content per food load. However, for little auks, longer foraging trips and a reduced provisioning rate are likely to have consequences, in terms of energy, that will be exacerbated if prey conditions deteriorate further. For example, in an inter-colony comparison of common murres, Davoren \& Montevecchi (2003) found that the colony with longer foraging trips and lower provisioning rates produced fledglings in poor condition.

In the past decade, the Greenland Sea has experienced warmer temperatures due to increased influx of North Atlantic water in the WSC (Schlichtholz \& Goszczko 2006, Walczowski \& Piechura 2007). Projected water mass distributions for the period 2080 to 2100 indicate future large-scale increases in Atlanticderived water in the Greenland Sea (Karnovsky et al. 2010). Falk-Petersen et al. (2007) predict that further Atlantic inflow will cause Calanus finmarchicus to become the dominant copepod species in the region. It is possible that a transition to warmer conditions typical of the North Atlantic will force little auks throughout the Greenland Sea to forage on this smaller, sub-optimal prey. A potential threshold exists beyond which little auks cannot increase foraging effort to meet their energy demands and those of their chicks. For instance, Ronconi \& Burger (2008) found that marbled murrelets (Brachyramphus marmoratus) could not adequately buffer against extremely poor foraging conditions through increased foraging effort. Increased effort would probably manifest itself as foraging behavior similar to that exhibited by Kongsfjord birds. This inter-colony comparison of little auk foraging behavior provides insight into how these top predators may respond to future warming trends in the Greenland Sea.

Acknowledgements. We thank N. Baldwin, D. Buchner, J. Fort, R. Orben, E. Weston, M. A. Pella-Donnelly, and $\mathrm{K}$. Holser for their hard work in the field. This study was done under the animal care permits of the Norwegian Animal Care Committee, the Pomona College Institutional Animal Care and Use Committee, the Ethics Committee of the French Polar Institute (MP/12/24/05/05), and with the permission of the Greenland Home Rule Government, Ministry of Environment and Nature (Danish Polar Center Scientific Expedition Permit 512-240), and the Governor of Svalbard. Funding was provided by the National Science Foundation (grant no. 0612504 to N.J.K. and A.H., grant no. 0301469 to
N.J.K.), French Polar Institute Paul-Emile Victor (Grant 388 to D.G.) and the Andrew W. Mellon Foundation (grant to N.J.K. and Z.W.B.). We thank the 29th expedition members of the Polish Polar Station of the Institute of Geophysics, Warsaw, Poland, for their support of this project, and NANU travel for the logistics at Greenland.

\section{LITERATURE CITED}

Aagaard K, Foldvik A, Hillman SR (1987) The West Spitsbergen Current: disposition and water mass transformation. J Geophys Res 92:3778-3784

Axelrod J, Reisine TD (1984) Stress hormones: their interaction and regulation. Science 224:452-459

Blachowiak-Samolyk K, Søreide JE, Kwaśniewski S, Sundfjord A, Hop H, Falk-Petersen S, Hegseth EN (2008) Hydrodynamic control of mesozooplankton abundance and biomass in northern Svalbard waters $\left(79-81^{\circ} \mathrm{N}\right)$. Deep-Sea Res II 55:2210-2324

Bourke RH, Newton JL, Paquette RG, Tunnicliffe MD (1987) Circulation and water masses of the East-Greenland Shelf. J Geophys Res 92:6729-6740

Bradstreet MSW, Brown RGB (1985) Feeding ecology of the Atlantic Alcidae. In: Nettleship DN, Birkhead TR (eds) The Atlantic Alcidae. Harcourt Brace Jovanovich, London

Cairns DK, Bredin KA, Montevecchi WA (1987) Activity budgets and foraging ranges of breeding common murres. Auk 104:218-224

Croll DA, Gaston AJ, Noble DG (1991) Adaptive loss of mass in thick-billed murres. Condor 93:496-502

$>$ Croll DA, Gaston AJ, Burger AE, Konnoff D (1992) Foraging behavior and physiological adaptation for diving in thick-billed murres. Ecology 73:344-356

> Davoren GK, Montevecchi WA (2003) Consequences of foraging trip duration on provisioning behaviour and fledging condition of common murres. J Avian Biol 34: 44-53

Falk K, Benvenuti S, Dall'Antonia L, Gilchrist G, Kampp K (2002) Foraging behaviour of thick-billed murres breeding in different sectors of the North Water Polynya: an inter-colony comparison. Mar Ecol Prog Ser 231:293-302

Falk-Petersen S, Timofeev S, Pavlov V, Sargent JR (2007) Climate variability and possible effects on arctic food chains: the role of Calanus. In: Orbaek JB et al. (eds) Arctic-alpine ecosystems and people in a changing environment. Springer, Berlin

Harding AMA, Van Pelt TI, Lifjeld JT, Mehlum F (2004) Sex differences in little auk Alle alle parental care: transition from biparental to paternal-only care. Ibis 146:642-651

Harding AMA, Piatt JF, Schmutz JA, Shultz MT, Van Pelt TI, Kettle AB, Speckman SG (2007) Prey density and the behavioral flexibility of a marine predator: the common murre (Uria aalge). Ecology 88:2024-2033

> Hirche HJ (1991) Distribution of dominant calanoid copepod species in the Greenland Sea during late fall. Polar Biol 11:351-362

Hop H, Pearson T, Hegseth EN, Kovacs KM and others (2002) The marine ecosystem of Kongsfjorden, Svalbard. Polar Res 21:167-208

Karnovsky NJ, Hunt GL Jr (2002) Estimation of carbon flux to dovekies (Alle alle) in the North Water. Deep-Sea Res II 49:5117-5130

> Karnovsky NJ, Kwaśniewski S, Wȩsławski JM, Walkusz W, 
Beszczyńska-Möller A (2003) Foraging behavior of little auks in a heterogeneous environment. Mar Ecol Prog Ser 253:289-303

Karnovsky NJ, Harding AMA, Walkusz W, Kwaśniewski S and others (2010) Foraging distributions of little auks Alle alle across the Greenland Sea: implications of present and future Arctic climate change. Mar Ecol Prog Ser 415:283-293

Kenward R (1987) Wildlife radio tagging. Equipment, field techniques and data analysis. Academic Press, London

Kuroki M, Kato A, Watanuki Y, Niizuma Y, Takahashi A,Naito Y (2003) Diving behavior of an epipelagically feeding alcid, the rhinoceros auklet (Cerorhinca monocerata). Can J Zool 81:1249-1256

Kwaśniewski S, Gluchowska M, Jakubas D, WojczulanisJakubas K and others (2010) The impact of different hydrographic conditions and zooplankton communities on provisioning little auks along the west coast of Spitsbergen. Prog Oceanogr 87:72-82

Livezey BC (1988) Morphometrics of flightlessness in the Alcidae. Auk 105:681-698

Moline MA, Karnovsky NJ, Brown Z, Divoky GJ and others (2008) High latitude changes in ice dynamics and their impact on polar marine ecosystems. Ann NY Acad Sci 1134:267-319

Monaghan P, Walton P, Wanless S, Uttley JD, Burns MD (1994) Effects of prey abundance on the foraging behaviour, diving efficiency and time allocation of breeding guillemots Uria aalge. Ibis 136:214-222

R Development Core Team (2008) R: A language and environment for statistical computing. R Foundation for Statistical Computing, Vienna. http://www.R-project. org.

Ronconi RA, Burger AE (2008) Limited foraging flexibility: increased foraging effort by a marine predator does not buffer against scarce prey. Mar Ecol Prog Ser 366: 245-258

Schlichtholz P, Goszczko I (2006) Interannual variability of the Atlantic water layer in the West Spitsbergen Current at 76.5 ${ }^{\circ} \mathrm{N}$ in summer 1991-2003. Deep-Sea Res I 53:608-626

Schreer JF, Kovacs KM, O'Hara Hines RJ (2001) Comparative diving patterns of pinnipeds and seabirds. Ecol Monogr 71:137-162

Scott CL, Kwaśniewski S, Falk-Petersen S, Sargent JR (2000) Lipids and life strategies of Calanus finmarchicus, Calanus glacialis and Calanus hyperboreus in late autumn, Kongsfjorden, Svalbard. Polar Biol 23:510-516
Stempniewicz L (2001) Alle alle little auk. BWP update. J Birds West Palearctic 3:175-201

Taylor JRE (1994) Changes in body mass and body reserves of breeding little auks (Alle alle L.). Pol Polar Res 15: 147-158

Tremblay Y, Cherel Y, Oremus M, Tveraa T, Chastel O (2003) Unconventional ventral attachment of time-depth recorders as a new method for investigating time budget and diving behaviour of seabirds. J Exp Biol 206: 1929-1940

Uttley JD, Walton P, Monaghan P, Austin G (1994) The effects of food abundance on breeding performance and adult time budgets of guillemots Uria aalge. Ibis 136: 204-212

> Walczowski W, Piechura J (2007) Pathways of the Greenland Sea warming. Geophys Res Lett 34:L10608, doi:10. 1029/2007GL029974

> Welcker J, Harding AMA, Karnovsky NJ, Steen H, Strøm H, Gabrielsen GW (2009) Flexibility in the bimodal foraging strategy of a high Arctic alcid, the little auk Alle alle. J Avian Biol 40:388-399

Wȩsławski JM, Stempniewicz L, Galaktionov KM (1994) The food and feeding of the little auk from Franz Josef Land. Polar Res 13:173-181

Wȩsławski JM, Stempniewicz L, Mehlum F, Kwaśniewski S (1999) Summer feeding strategy of the little auk Alle alle from Bjornoya, Barents Sea. Polar Biol 21:129-134

Wȩsławski JM, Kwaśniewski S, Stempniewicz L, Błachowiak-Samołyk K (2006) Biodiversity and energy transfer to top trophic levels in two contrasting Arctic fjords. Pol Polar Res 27:259-278

Wilson R, Culik B (1994) Hydrodynamic aspects of design and attachment of a backmounted device in penguins. J Exp Biol 194:83-96

Wilson R, Culik B (1992) Packages on penguins and deviceinduced data. In: Priede IG, Swift SM (eds) Wildlife telemetry: Remote monitoring and tracking of animals. Ellis Horwood, Chichester

Wilson RP, Culik BM, Peters G, Bannasch R (1996) Diving behaviour of Gentoo penguins, Pygoscelis papua; factors keeping dive profiles in shape. Mar Biol 126:153-162

Wingfield JC, Vleck CM, Moore MC (1992) Seasonal changes of the adrenocortical response to stress in birds of Sonoran Desert. J Exp Zool 264:419-428

> Ydenberg RC, Clark CW (1989) Aerobiosis and anaerobiosis during diving by western grebes: an optimal foraging approach. J Theor Biol 139:437-449 
Appendix. Assessment of the effects of TDRs

We assessed potential effects of time-depth recorders (TDRs) on breeding little auks in a number of ways: (1) changes in corticosteroid hormone (CORT) levels, (2) growth rates of chicks of instrumented and non-instrumented parents, (3) colony observations, and (4) weight loss of instrumented and non-instrumented birds.

Corticosteroid hormone levels. At the Kongsfjord and Greenland colonies, $\sim 5 \mathrm{ml}$ of blood were taken upon initial capture when the TDRs were deployed, and upon recapture when the TDRs were removed. We extracted plasma using a microcentrifuge and preserved it using an equal amount of ethanol. Radioimmunoassay analysis (see Wingfield et al. 1992 for detailed methods) allowed us to assess changes in CORT levels, which reflect stress levels in birds (Axelrod \& Reisine 1984). We compared CORT levels of recaptured birds equipped with TDRs to the CORT levels of recaptured noninstrumented birds over the same period of time.

We obtained CORT levels for 8 instrumented birds (5 at Kongsfjord, 3 at Greenland) upon both capture and recapture; birds had marginally elevated CORT levels upon recapture compared to the initial level (paired-samples 2-tailed $t$-test: $\mathrm{p}=$ 0.043). However, we found no difference at Kongsfjord or Greenland between the CORT levels of recaptured instrumented and non-instrumented birds (Kongsfjord $\mathrm{n}=22$, Greenland $\mathrm{n}=17$ ) (2-tailed $t$-tests: Kongsfjord $\mathrm{p}=0.319 ;$ Greenland $\mathrm{p}=$ $0.741)$.

Chick growth rates. At the Hornsund colony, every $3 \mathrm{~d}$ we measured and compared the weights of chicks of known age with and without a TDR-equipped parent. To minimize disturbance, we did not make any chick measurements while the parent carried a TDR but resumed measurements after the TDRs had been retrieved. We ran a linear model with chick weight as the response variable and age and TDR-parent as fixed explanatory variables, including their interaction, and we included individual as a random effect. We measured 56 chicks (including 8 TDR chicks) 1 to 8 times each. We found that, at a given age, chicks with a TDR-equipped parent were slightly lighter than those without $\left(\mathrm{LM}: F_{1,163}=4.220 ; \mathrm{p}=\right.$ 0.0416).

Colony observations. We also observed birds at the colony opportunistically during TDR deployment and after the TDRs had been removed to determine whether the birds continued to feed their chicks normally. Six of the 11 experimental birds in Hornsund, and all 7 birds at Kongsfjord, were observed feeding chicks during TDR attachment. In addition, 6 Hornsund birds were observed feeding chicks post-TDR removal. In Greenland, no observations were attempted during this period; however, 2 instrumented birds had chick meals upon recapture, indicative of feeding. TDR temperature and depth data clearly showed high diving activity and regular returns to the colony for all birds.

Adult weight loss. Finally, we compared the birds' weights upon capture and recapture to determine how well adults maintained their own body condition while carrying the TDR. In Greenland, we measured the weights of 4 of the 6 experimental birds at the start and end of TDR deployment: 3 had lost weight and 1 had gained weight. In Hornsund, of the 9 birds we weighed, we found that 7 had lost weight and 2 had gained weight. In Kongsfjord, we measured the weights of all 7 experimental birds: 3 had gained weight, 3 had lost weight, and 1 remained the same. Overall, we found that little auks at the end of TDR deployment were marginally lighter than at the start (paired-samples 2-tailed $t$-test: $\mathrm{n}=20 ; \mathrm{p}=$ 0.029). The average weight loss for the 20 measured birds was $5.1 \pm 9.6 \mathrm{~g}$, or a loss of $3.1 \%$ of the average initial mass, or $-0.9 \%$ of initial mass for each day of deployment.

Overall, with the exception of brief periods of anomalous readings just after logger attachment (perhaps when the bird was preening the device), experimental birds did not appear to exhibit atypical behavior. On the basis of temperature and depth data recorded by the TDRs, as well as direct observations of TDR-equipped birds, we know that birds carrying TDRs were regularly foraging at sea and bringing back food for chicks. At the Hornsund colony we found that chicks with a TDRequipped parent continued to gain weight. One chick at Hornsund died during TDR attachment due to the collapse of its nest site. We saw its parent with a distended gular pouch, attempting to feed its chick after it had died. We were not able to retrieve this TDR and it was not used in our analyses. We found that TDRs did not clearly increase stress as reflected in CORT levels measured at the Greenland and Kongsfjord colonies (there were no significant differences in CORT levels between TDR-carrying birds and non-instrumented birds, and CORT differences between capture and recapture were minimal).

The low impact of the TDRs was probably due to their small size. Kenward (1987) suggested that, at $3 \%$ of body mass, birds begin to be hampered by attached data loggers, while Wilson \& Culik (1992) suggested that devices weighing $<5 \%$ of the bird's weight cause little impediment. In the current study, TDRs were $\sim 1.6 \%$ of the initial body mass of experimental birds and $2.1 \%$ of the birds' cross-sectional area, which is low compared to earlier studies of diving in Alcids (Cairns et al. 1987, Croll et al. 1992, Kuroki et al. 2003). On average, little auks with TDRs lost $0.9 \%$ of their initial mass per day during logger deployment. Unfortunately, we have no measure of mass loss of unencumbered birds during the same time period. While mass loss during chick rearing to improve flying efficiency may be a natural pattern for some Alcids (e.g. Croll et al. 1991), little auks have been known to maintain relatively constant body mass after initially losing weight after the chick hatches (Taylor 1994).

Editorial responsibility: John Piatt, Anchorage, Alaska, USA
Submitted: April 4, 2011; Accepted: August 9, 2011

Proofs received from author(s): October 24, 2011 